News, Notes and Queries

\begin{tabular}{|c|c|c|c|}
\hline $1733-1760$ & $\begin{array}{l}\text { ANDREW SINCLAIR } \\
\text { Died } 25 \text { Oct. } 1760 \text { (Ibid). }\end{array}$ & 24 Feb. 1733 & Ibid., viii, 37 \\
\hline $1761-1766$ & $\begin{array}{l}\text { ROBERT WHYTE } \\
\text { Died } 15 \text { Apr. } 1766 \text { (Ibid.) }\end{array}$ & 13 Apr. 1761 & Ibid., ix, 140 \\
\hline $1766-1773$ & $\begin{array}{l}\text { JOHN GREGORY } \\
\text { Died } 9 \text { Feb. } 1773 \text { (Dict. Nat. } \\
\text { Biog.) }\end{array}$ & 12 May 1766 & Ibid., ix, 456 \\
\hline $1773-1790$ & $\begin{array}{l}\text { WILliam CULlen } \\
\text { Died } 5 \text { Feb. } 1790 \text { (Dict. Nat. } \\
\text { Biog.) }\end{array}$ & 18 Mar. 1773 & Ibid, x, 211 \\
\hline $1790-1799$ & $\begin{array}{l}\text { JOSEPH BLACK } \\
\text { Died } 6 \text { Dec. } 1799 \text { (Dict. Nat. } \\
\text { Biog.) }\end{array}$ & 8 Mar. 1790 & $\begin{array}{l}\text { Privy Seal Warrants } \\
1790 \text { No. } 6\end{array}$ \\
\hline $1799-1821$ & $\begin{array}{l}\text { JAMES GREGORY } \\
\text { Died } 2 \text { Apr. } 1821 \text { (Dict. Nat. } \\
\text { Biog.) }\end{array}$ & 18 Dec. 1799 & $\begin{array}{l}\text { Privy Seal (English } \\
\text { Record) xii, } 216\end{array}$ \\
\hline $1821-1828$ & $\begin{array}{l}\text { ANDREW DUNCAN } \\
\text { Died } 5 \text { July } 1828 \text { (Dict. Nat. } \\
\text { Biog.) }\end{array}$ & 10 Apr. 1821 & Ibid,. xiv, 229 \\
\hline $1828-1844$ & $\begin{array}{l}\text { JOHN ABERCROMBIE } \\
\text { Died } 14 \text { Nov. } 1844 \text { (Dict. Nat. } \\
\text { Biog.) }\end{array}$ & 22 July 1828 & Ibid, xiv, 449 \\
\hline
\end{tabular}

\title{
THOMAS HODGKIN (1798-1866) ON CANCER CELL CARRIAGE
}

IT is a hundred years since the death of Thomas Hodgkin who, in 1832, waded into the mass of ill-defined diseases that affect the sprawling reticulo-endothelial system of the body and fished out the gem among them. 'At the center of this orbit,' wrote Doan ${ }^{1}$ concerning the diseases of this system a decade ago, 'is the clinicopathologic syndrome which continues to bear Hodgkin's name'.

Following its delineation, the nature of this disease has been a matter for controversy. Since that time, in the opinion of Moore' in 1951, "little progress has been made in the understanding of the nature of the condition beyond the proposal of more than fifty terms as synonyms'. Willis ${ }^{3}$ wrote: 'The fact that the name "Hodgkin's disease" has persisted in spite of all competitors, and that most pathologists are quite clear as to the characters of the lesion so designated, is significant.'

In his popular book on diagnosis, Chamberlain ${ }^{4}$ recently honoured Hodgkin by giving an illustration of him with the caption, 'Philanthropist and Curator of the Pathological Museum, Guy's Hospital'. In a further honour to his memory, I wish to spotlight his pathological observations with special reference to my own field of research, namely, the mode of spread of cancer from one part of the body to another. 


\section{News, Notes and Queries}

Naegeli ${ }^{5}$ pointed out that Hodgkin's delineation of his cases was done 'in a masterly way and with astonishing clearness'. This is a true reflection of Hodgkin who was always at pains to systematize observed facts. Thus, 'almost from the commencement of my pathological studies', he himself ${ }^{6}$ narrated in 1848 , he was 'impressed both with the difficulty and with the importance of connecting those minute molecular changes which are on the confines of visibility, or even beyond its limits, with those larger results which become the objects of demonstrable morbid anatomy ...'

Or, as he wrote in $1836,{ }^{7}$ 'It is only by collecting into one view the various alterations which disease effects in any particular tissue, that we can hope to arrive at an accurate knowledge of the relation which these modifications bear to each other, and to the healthy state'.

Earlier, in $1829,{ }^{8}$ he had emphasized the importance, in studying the mode of spread of cancer, of: 'enumeration of those characters, the whole or greater number of which concur in cases to which the appelation of malignant has by common consent been applied.'

In that year ${ }^{8}$ and a few years later ${ }^{9}$, before the dawn of the era of the microscope, he maintained that the lymph nodes in the path of the lymph vessels draining the original organ attacked by cancer 'became enlarged, by a deposit having very much the character possessed by the original tumour'. This conclusion based on naked eye appearances was that of an alert mind which was to stand him in good stead when the microscope ultimately took the stage: ${ }^{10}$

In the autumn of 1838 , I paid a transient visit to Berlin, where I had the pleasure of receiving from Professor Schwann a demonstration of the nucleated cells, pointed out by himself and Schlein as performing an important and essential part in the formation of vegetable and animal tissues. I procured, at the same time, the important work of Professor Muller on the structure of cancer and other adventitious structures, which had then very recently appeared. I likewise inspected the preparations in the museum of the university, relating to this subject, which had been made by Muller himself ... .

The most practised eyes, and the best instruments, have been employed in these observations, and the results obtained have been so generally in accordance, that, notwithstanding the doubts which are attached by some to microscopic inquiries, they may be received with confidence, although from the optical characters of the objects themselves, their examination is often difficult.

Consequently, we find Hodgkin ${ }^{6}$ in the forefront of those who, early in the day, accepted the cellular basis of cancer carriage. 'When the disease has shown itself in different parts', he argued, 'the striking similarity presented by the molecules taken from each of them, strongly favours the idea of family connection, and consequently of transfer'. 'Are we,' he asked, 'to suppose that some predisposing cause favours the production de novo of the disease in each of these parts, or rather that their peculiarity consists in some power which arrests certain molecules already in the circulation, and that so arrested, they become fresh starting points for the production of the morbid growth?' 'I incline,' he answered correctly, 'to the latter opinion, more particularly on account of the remarkable similarity in the microscopic characters of the morbid molecules taken from different parts of the same person.'

The significance of these enlightened views lies in the fact that, as I have shown elsewhere, ${ }^{11}$ several other authorities were tardy in accepting the cellular theory of metastasis, clinging long to the old humoral concepts. Indeed, although the great 


\section{News, Notes and Queries}

Virchow fathered cellular pathology, he was, as I also showed, ${ }^{12}$ a firm protagonist of humoral concepts, when it came to cancer carriage. It is sastifying, therefore, to find that Macdonald 18 recently classed Hodgkin with John Hunter as one of the founders of the British school of pathological anatomy of cancer.

Hodgkin's enlightenment is mirrored also in his appreciation of the surgical pathology of cancer. My review of historical trends 14 in cancer surgery gives dates which show that Hodgkin was ahead of his times, for he counselled, as far back as $1843,{ }^{10}$ that in operating for the removal of a tumour of this class, it is extremely important to leave behind none of those minute cysts which often form granules in the surrounding cellular membrane, though it may appear to be in other respects perfectly healthy: this appears to be a mode of extension of the disease, independent of inflammation.

Let us consider the stages of metastasis as outlined by Hodgkin. ${ }^{6} \mathrm{He}$ appreciated that cancer may long remain confined and later break, as it were, out of bounds. 'The long period during which the disease may remain strictly local seems to indicate,' he thought, "that in the healthy system there is some barrier to the ready transfer of the newly-formed morbid molecules to the different parts of the body ...'

He knew that, after the invasion of the local tissues, the distant parts became invaded, the most frequent organ so involved being the liver, ${ }^{8}$ while a rare site was the substance of the heart. ${ }^{15} \mathrm{He}$ was aware, too, that ${ }^{16}$

This disease ... also extends to the lymphatic glands, through which the absorbent vessels pass, in their way to the thoracic duct or right trunk. This, however, is not the only mode in which the disease extends from the part first affected. The veins leading from it are said to have been found filled with the cerebriform matter which characterizes this disease, and the fact has been adduced as an argument in favour of venous absorption; whilst, on the other hand, the advocates for lymphatic absorption have, with equal plausibility, brought forward the presence of cerebriform matter, not only in the absorbent glands, but also in the absorbent vessels themselves.

We observe, from the above passage, that the present interest in the role of the thoracic duct ${ }^{17}$ as a conduit for cancer cells was anticipated by Hodgkin, who was clearly aware that the duct was a final pathway for such cancerous dispersal. We note, also, that Hodgkin neatly balanced the arguments between the supporters of venous and lymphatic carriage of tumour tissue from the primary seat of the disease. Elsewhere ${ }^{18,19} \mathrm{I}$ have shown that the views, which were then beginning to crystallize out, bear the modern stamp, but let Hodgkin himself put the concepts in perspective:10

At the same time, I would by no means deny the possibility, or even probability, that some of the nucleated cells may find their way into the blood, and be arrested at particular parts, giving rise to productions similar to the original tumour, more especially when the latter has advanced to the softening stage, and the lymphatic glands have become affected.

Hodgkin described the distribution patterns of the spreading cancer cells sucinctly:?

Besides the affection of the glands situated in the course of the circulation, and, at times, without this having sensibly taken place, other parts of the body become the seats of similar deposits. Occasionally, deposits of this kind take place simultaneously in very many structures and parts of the body. At other times, they are confined to very few organs, or even to a single organ; in which case, the selection of the organ or organs, in which such deposit occurs, appears to be very much influenced by the seat of the primary affection. 


\section{News, Notes and Queries}

In the above passage are outlined some important problems which are still being clarified in our own age. First, there is the question of the non-invasion of some lymph nodes which would normally be expected to have been invaded. This phenomenon, currently referred to as 'skipping metastasis', is, as I enunciated it, ${ }^{20}$ an illustration of one of the important laws of lymphatic spread of cancer.

Secondly, he mentioned cases with cancer deposits dispersed to several parts of the body. I believe that this distinct group can be separated from the general run of cases and ought to be purposely studied collectively, having shown myself ${ }^{21}$ that among them are numbered cases with cancer embolus in the glomerulus of the kidney-an anatomical unit which is structurally suited to trap the cancer embolus but, most curiously, seldom does so.

Thirdly, he spotlighted the occurrence of metastases limited to a few organs. $\mathrm{I}^{22}$ have pointed out that such cases are vastly in the majority, even in cancer of the lung -an organ whose anatomical position endows it with priceless opportunities for distant dispersal.

Fourthly, we come finally to his mention of the singling out of particular tissues during the invasion process, a phenomenon termed 'selectivity of metastasis' in our own age. Hodgkin illustrated: ${ }^{6}$

The determination of the parts of the system in which the secondary formations are to take place is another subject of very interesting inquiry. I do not remember to have ever seen this more strikingly exhibited than in the case of W.C., in which the new growth made its appearance on the confines of the bony tissue, near its junction with cartilage.

Elsewhere, he mused ${ }^{10}$ : 'The superior tendency which particular textures, and even particular parts of textures, exhibit to the production of these structures, when the system has become affected, is more worthy of remark, than easy of explanation.'

As ${ }^{23}$ illustrated in the case of Reid, his Scottish contemporary, Hodgkin tried to explain the localization of secondary deposits in such selected organs on the grounds of 'sympathy' but he was conscious of the fact that this explanation was unsatisfactory" :These secondary tumors are often produced in a manner of which we can give no other explanation, than an unsatisfactory reference to the mysterious sympathy which connects particular organs, both pathologically and physiologically.'

To illustrate the existence of 'sympathy', Hodgkin' cited a group of lymph nodes whose invasion is often strikingly seen at the post-mortem table and whose microscopical study should, I think, ${ }^{25}$ command special attention. I refer to the lymph nodes around the pancreas of which Hodgkin particularized :8

Some of the instances of this kind afford curious proofs of the inexplicable sympathy existing between remote organs; thus, in a case of fungoid disease affecting an absorbent gland in the neighbourhood of the parotid, glands of a similar description, situated near the upper edge of the pancreas, were found enlarged, and participating in the disease.

In this connection, I have italicized, above, the name by which Hodgkin preferred to call tumours of the exuberant fungating type, for his tidy and systematic mind revolted against the use of several names for the same entity $:^{\text {' }}$ Thus we find the terms encephaloid tumours, cerebriform cancer, medullary sarcoma, spungoid inflammation, fungus hematodes, and fungoid disease. I am rather inclined to prefer the last of these terms ...' 


\section{News, Notes and Queries}

It was originally held that cancer arose in the lymphatic system. ${ }^{26}$ Later, as cancerous tissue began to be recognized also in the blood vessels, there was a swing to the view that cancer was a disease arising in the blood. Hodgkin appreciated that the presence of such cancerous matter in the vessels was an embodiment not of formation but of transportation ${ }^{24}$ and, accordingly, dismissed the theory: ${ }^{10}$ Instances of this kind have been adduced in favour of the theory that malignant disease commences by the production of an abnormal principle in the blood, an idea which appears to me equally untenable in theory and in fact.

The transporting system of the body was Hodgkin's abiding interest. He began a fruitful life of research by writing at the age of twenty-five his Edinburgh thesis, de Absorbendi Functione ${ }^{15}$, in which:

some facts are also brought forward, which make it appear not altogether improbable that these vessels are subservient to a process of separation; that, although some fluids may be carried by either set of vessels indiscriminately, other substances are restricted to one of them; in fact, that whilst the Lymphatic Vessels act more particularly on those fluids which possess an alkaline tendency, the Veins, on the other hand, admit the acids and substances allied to them.

To conclude, have we a lesson here? Much as the above views on the function of the lymphatics and veins are now outdated, it seems to me that Hodgkin's central theme, namely, that the transportation roles of lymph and blood differ, is a matter for both present and future research. Certainly, in our quest to explain, as Hodgkin tried, the mystery of the spread of cancer in the body, there is need to exploit any differences, however small, between lymph and blood.

\section{REFERENCES}

1. Doan, C. A., 'The reticuloendothelial system', In The Practice of Medicine, ed. by J. C. Meakins, London and St. Louis, Henry Kimpton, 1956, p. 1489.

2. MoOre, R. A., A Textbook of Pathology, 2nd ed., Philadelphia and London, W. B. Saunders, 1951, p. 822.

3. Willis, R. A., Pathology of Tumours, 2nd ed., London, Butterworth, 1953, p. 771.

4. Chamberlain, E. N., Symptoms and Signs in Clinical Medicine, 7th ed., Bristol, John Wright, 1961, p. 274.

5. NaEgeli. See Willis, Op. cit., p. 771.

6. HodGKIN, ThOMAs, 'Cases illustrative of some consequences of local injury', Med.-Chir. Trans., 1848, 31, 253-83.

7. Lectures on the Morbid Anatomy of the Serous and Mucous Membranes, vol. 1,1836, p. 15.

8. 'On the anatomical characters of some adventitious structures', Med.-Chir. Trans., 1829, 15, 265-338.

9. 1836, Op. cit., p. 264.

10. 'On the anatomical characters of some adventitious structures, being an attempt to point out the relation between the microscopic characters and those which are discernible by the naked eye', Med.-Chir. Trans., 1843, 26, 242-85.

11. Onuigbo, Wilson I. B., 'A history of the cell theory of cancer metastasis', Gesnerus 1963, 20, 90-95.

12. 'The paradox of Virchow's views on cancer metastasis', Bull. Hist. Med., 1962, 36, 444-49. 


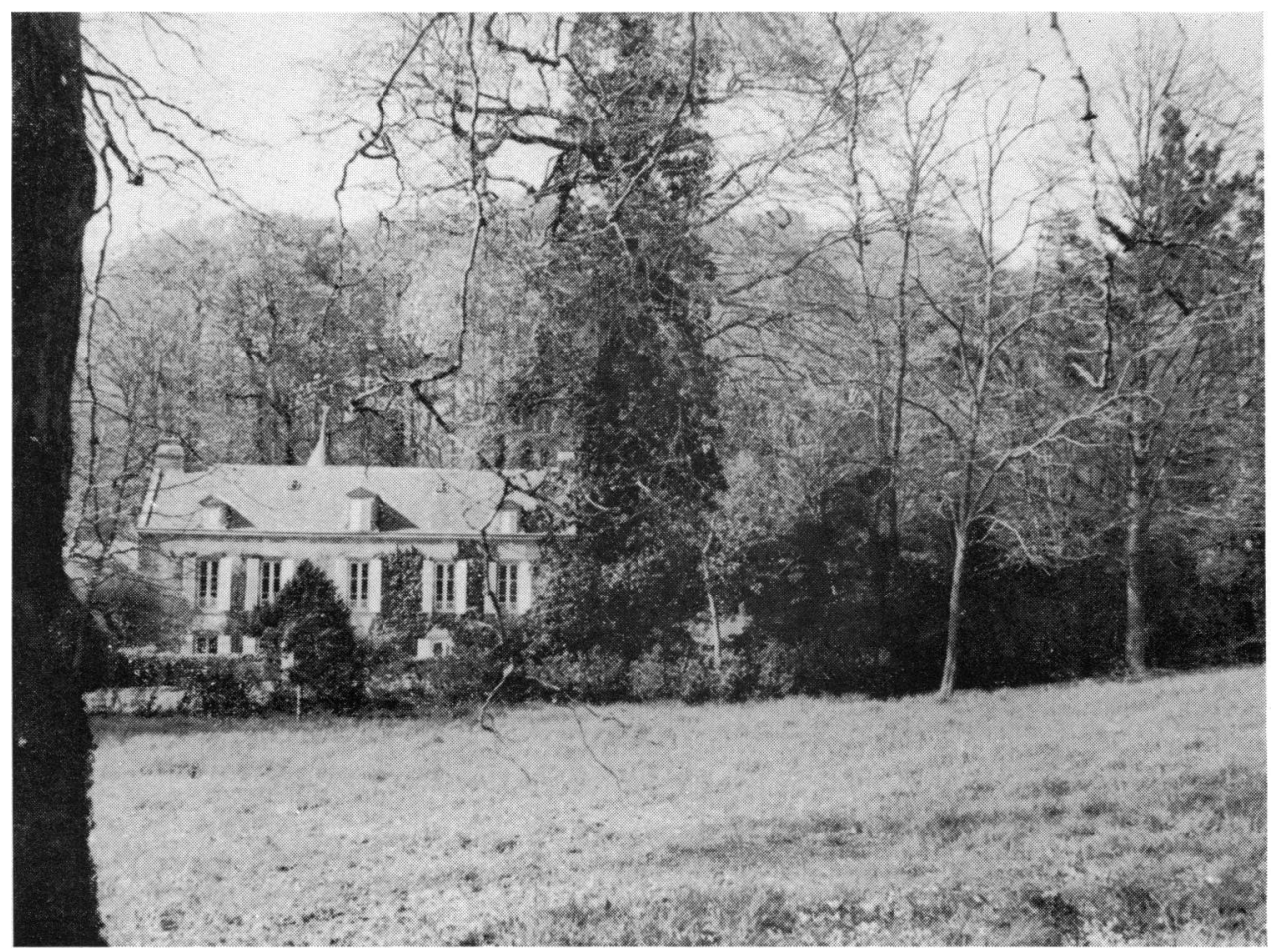

Figure 1.

Laënnec's house Kerlouarnec, near Douarnenez, seen from the front.

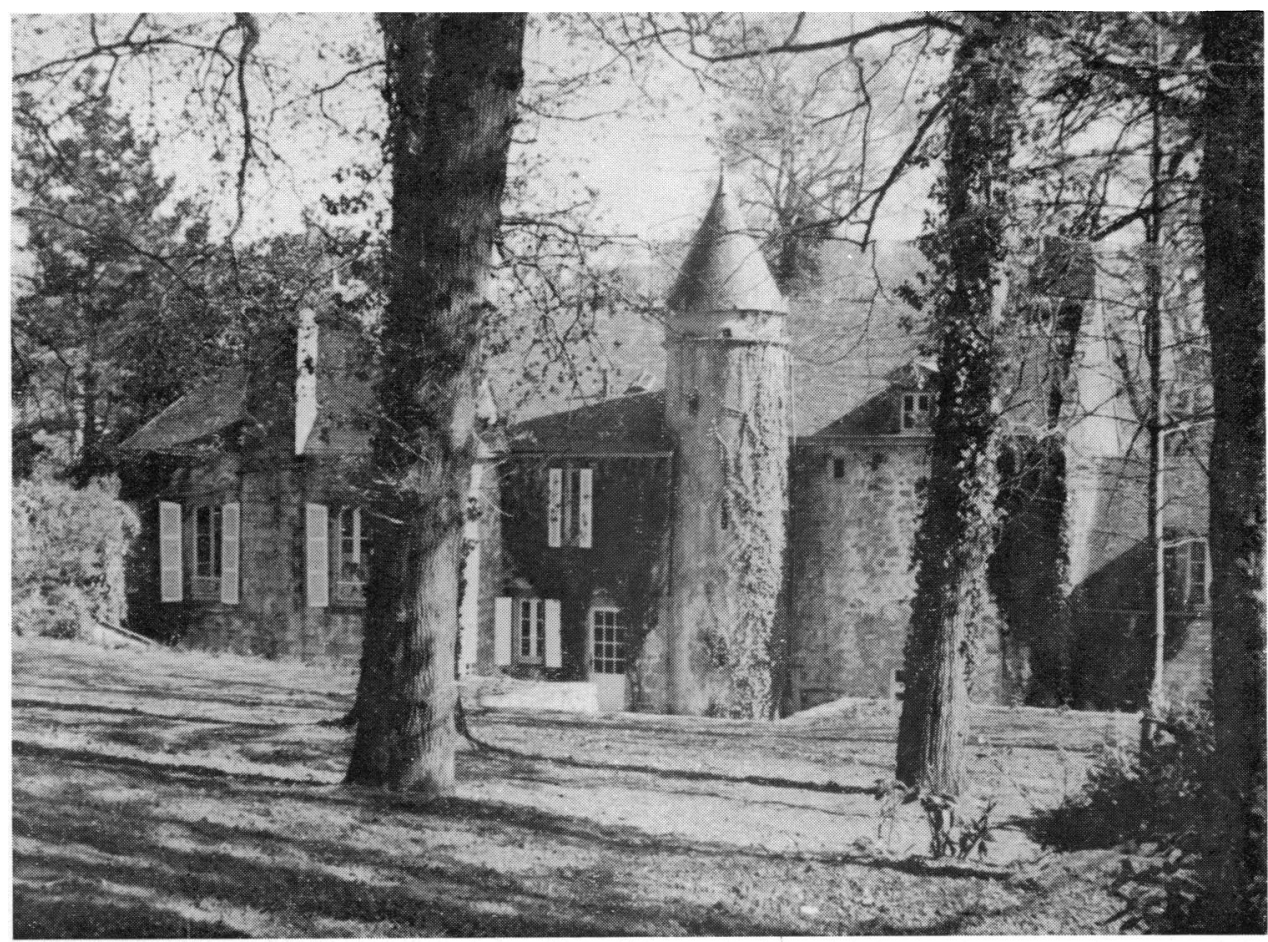

Figure 2. (Photographs by courtesy of Monsieur A. Halna du Fretay.)

Back view of Kerlouarnec. 


\section{News, Notes and Queries}

13. Macdonald, Eleanor J., 'Historical trends in cancer', In Cancer. A Manual for Practitioners, 3rd ed., 1956, p. 2.

14. Onuigbo, WiLson I. B., 'Historical trends in cancer surgery', Med. Hist., 1962, 6, 154-61.

15. Hodgrin, Thomas, A Catalogue of the Preparations in the Anatomical Museum at Guy's Hospital, Section III, 1829b, unpaginated.

16. 1836, Op. cit., p. 290.

17. Onuigbo, Wilson I. B., 'The carriage of cancer cells by the thoracic duct', Brit. J. Cancer, in press.

18. -An historical criticism of tumor metastasis', J. Hist. Med., 1958, 13, 529-31.

19. - 'The age-old dictum on the spread of tumours', Centaurus, 1963, 8, 263-68.

20. 'Lymph node metastases in lung cancer', Geriatrics, 1964, 19, 380-88.

21. 'An index of the fate of the circulating cancer cells', Lancet, 1963, ii, 828-31.

22. 'The limitation of metastases in lung cancer', Tubercle, 1961, 42, 248-51.

23. 'John Reid (1809-1849) and Horner's syndrome', Scot. med. J., 1958, 3, 218-20.

24. HodgkIN, Thomas, 1836, Op. cit., p. 276.

25. ONUIGBo, WiLson I. B., 'Lung cancer metastasis to the pancreas and its surrounding lymph nodes', Brit. J. Dis. Chest, 1966, 60, 152-55.

26. Geudron, D. (Book Review), 'Researches on cancer', Phil. Trans., 1700, 22, 476-82.

WILSON I. B. ONUIGBO

\section{THE BACKGROUND OF LÄ̈NNEC (WITH PARTICULAR REFERENCE TO KERLOUARNEC)*}

Some time ago the Osler Club had a very interesting meeting on the subject of medical monuments. Among the many which were not mentioned that evening was one which I saw in the market place outside Quimper cathedral in Western Brittany two years ago. It shows Laënnec holding a stethoscope. At the back is the following inscription:

A l'Inventeur de l'auscultation-Laênnec René Théophile Hyacinthe né à Quimper le 17 Février 1781 mort à Plouaré en 1826 Professeur à la Faculté de Médecine de Paris et au Collège de France Membre de l'Académie de Médecine. Ce Monument a été élevé par l'Association Générale des Médecins de France par la Bretagne et par les Médecins Français et Étrangers. Mai 1868.

The sculptor was E. Le Quesne and at the base is a copper plate which states:

À Laěnnec. Centenaire du Traité de l'Auscultation. Le Conseil Générale de Finistère. La Ville de Quimper. La Société Archéologique du Finistère. Les Médecins du Finistère. 1919.

It is quite clear from holiday brochures, issued in Brittany, that Laënnec is regarded as the most eminent Breton of the last few centuries. This is not only because of his great contribution to medicine but also because he became an authority on the Breton language, literature and folk songs. He was not born, however, into a Bretonspeaking family but gained this knowledge in later life, especially from his relative, Madame de Pompéry, with whom he spent a holiday in 1805 . He took every opportunity to widen it; if he saw a Breton patient in hospital, he always spoke to him in that language, and this was much appreciated.

- A paper read to the Osler Club of London on 16 June 1966. 